\title{
WITHIN-STEM DENSITY VARIATIONS OF TWO LESSER-UTILIZED TIMBERS AND THEIR RELATED PRIMARY SPECIES
}

\author{
C. Antwi-Boasiako ${ }^{1}$ and J. R. Barnett ${ }^{2}$ \\ ${ }^{1}$ Department of Wood Science and Technology, \\ Kwame Nkrumah University of Science and Technology, Kumasi, Ghana. \\ ${ }^{2}$ School of Plant Sciences, The University of Reading, \\ Whiteknights, Reading, Berks, RG6 6AS, England, UK.
}

\begin{abstract}
Wood density often influences its quality, marketability and end-use. This paper provides information, for the first time, on the density variation within the stems of two members each of the Rubiaceae and the Tiliaceae from Ghana. From each family, the density at each stem position of a traditional species is compared with that of a related Lesser-Utilized Species (LUS). Density is determined using conditioned weight of each block at $20^{\circ} \mathrm{C}$ and $65 \%$ rh and its volume measured using a digital micrometer. Densities ranging from $720-820 \mathrm{~kg} / \mathrm{m}^{3}$ for Corynanthe pachyceras Welw., and 660 $-720 \mathrm{~kg} / \mathrm{m}^{3}$ for Nauclea diderrichii (de Wild.) Merr. (members of the Rubiaceae) were measured. Densities for the two members of the Tiliaceae are lower and range from $295-400 \mathrm{~kg} / \mathrm{m}^{3}$ for Glyphaea brevis (Sprengel) Monachino and $640-700 \mathrm{~kg} / \mathrm{m}^{3}$ for Nesogordonia papaverifera (A. Chev.) $R$. Capuron. Analysis of variance (ANOVA) is employed to examine differences in densities from different radial and axial stem positions as well as growth sites for the two (2) LUS. Results have shown that variations in density within the stems exist with density increasing generally from the outer sapwood to the inner heartwood. However, the trend is sometimes not clear for members of the Tiliaceae (G. brevis and $N$. papaverifera). It also varies along the stems of the four timbers often decreasing with height from the base to the crown. However, few irregularities also occur along the stems of the LUS. Moreover, this study has shown that growth site influences the within-stem densities of the LUS.
\end{abstract}

Keywords: End-use, heartwood combined, Lesser-Utilized Species, Rubiaceae, Tiliaceae, Within-stem density

\section{INTRODUCTION}

Density is often regarded as one of the non-toxic properties that likely promote wood commercialization because it is, more often than not, considered to influence wood characteristics including durability (Boyce, 1961; Schmidtling and Amburgey, 1977). It also affects the strength properties and quality of temperate and tropical wood species. For instance, density is one of the criteria in wood selection for constructional and super- 
structural purposes as well as several other specific uses including pulp yield and paper-making quality (Jozsa and Middleton, 1994). However, weight varies within each stem, as not every part of the stem position of a plant may possess the same density. This affects wood value within the various regions of each bole. Such differences in density within the stem also have effect on its hardiness, resistance against deterioration, strength and several other physical and mechanical properties including tension, compression, strain, shear, bending and cleavage across and along its entire stem. As a result, a number of studies have been made to examine density variation within the stems of various wood species including Douglas-fir and yellow-cypress by Jozsa and Middleton (1994). Moreover, in one temperate species, beech (Fagus sylvatica L.), often employed as control species in durability tests in EN standards (Anon., 1982; 1994a, b), Tsoumis (1991) found its density to decrease with distance from the pith. However, for tropical timbers, little if any, is known about density variations within their stems, particularly for Ghanaian species. This is against the backdrop that wood for certain end-uses that require strength may be taken from different parts of the log since not all parts of the stem have the same density or strength. For this reason, this paper describes in full the within-stem density variation for four timbers from two families, namely Rubiaceae (e.g. Nauclea diderrichii (de Wild.) Merr. and Corynanthe pachyceras Welw.) and Tiliaceae (i.e. Nesogordonia papaverifera (A. Chev.) R. Capuron and Glyphaea brevis (Sprengel) Monachino). For the traditionally known and widely used timbers (termed primary species) employed in the present investigation (i.e. $N$. diderrichii and $N$. papaverifera), only their mean densities of $750 \mathrm{~kg} / \mathrm{m}^{3}$ have been reported from unspecified portions of their stems (Bailey, 1933; Cauday and Maun, 1997). However, Kribs (1959) reported $45 \mathrm{lbcuft}$ (ca. $867 \mathrm{~kg} / \mathrm{m}^{3}$ ) for C. pachyceras, a Lesser-Utilized Species (LUS), while there are no density records for the other LUS, $G$. brevis. For the present study, the LUS were sam- pled from three Ghanaian growth sites since little is known about their properties; the effect of locality on their densities was therefore studied. Their within-stem density variations were compared as well as with those of their related traditional hardwoods sampled from one forest district.

\section{MATERIALS AND METHODS}

Single stems of $C$. pachyceras and G. brevis aged 45-75 years were cut at breast height from natural stands in three forest districts of Ghana: Bekwai, Nkawie, and Offinso all from the semi-deciduous forest. One stem of each species was taken from each site. However, single stems of $N$. diderrichii and $N$. papaverifera of about 50 years were taken from Nkawie. Wood was selected from six different growth rings from the pith: the inner heartwood (IHW) (3-8 growth rings), outer heartwood (OHW) (19-23), transition wood (TW) (23-28; this depended on the stem), inner sapwood (ISW) (28-32), middle sapwood (MSW) (33-37) and outer sapwood (OSW) (38-45 growth rings). The density at each position of the stem for individual species was determined from the volumes of 10 replicate blocks $(15 \times 10 \times 10 \mathrm{~mm})$. The dimensions of the volume were taken using a Mitutoyo Digital Micrometer. Densities (estimated as Mass/ Volume) were calculated using corrected ovendry weight (determined as in Antwi-Boasiako (2004)) and the conditioned-volume of the replicate stakes (at $20^{\circ} \mathrm{C}$ and $65 \% \mathrm{RH}$ ). Besides the individual radial positions, densities of the undifferentiated and conventionally known heartwood (i.e. combined IHW, OHW and TW) and sapwood (i.e. combined ISW, MSW and OSW) were compared. Within- and between-stem density variations for each species and at different growth sites (for the LUS) were determined and compared using Analysis of Variance (ANOVA). Correlation between their densities (from their bases) and durabilities following exposure to a white-rot fungus (Coriolus versicolor (L) Quelet) has been earlier reported (Antwi-Boasiako, 2004). 


\section{RESULTS}

The present investigations have revealed that wood taken from each position within the stem of C. pachyceras is denser than those from the two primary species including its related durable species, N. diderrichii. Although literature is silent on the density of $G$. brevis, this has been presently found to be the lightest ranging from 295$400 \mathrm{~kg} / \mathrm{m}^{3}$. Within-stem density variations for the two LUS (C. pachyceras and G. brevis) and their two respective related primary species $(N$. diderrichii and $N$. papaverifera) have been also determined for the first time. In general, radial and axial variations exist between and within all the species examined. Density variations for combined sapwood (OSW, MSW and ISW) and heartwood combined (IHW, TW and OHW) as well as
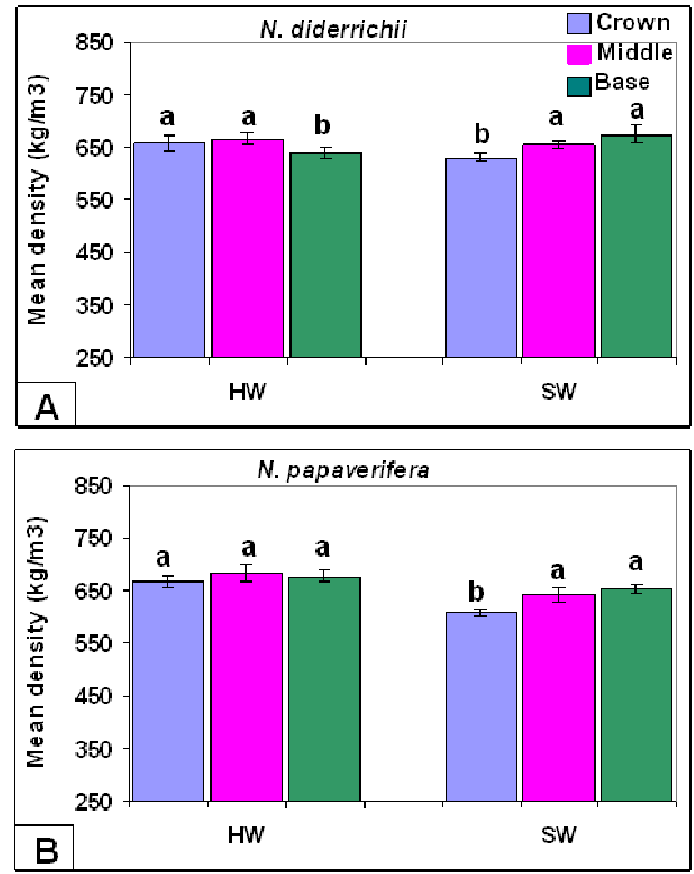

all the individual sapwood and heartwood regions across and along the stems and also from different growth sites are given below:

\section{Density variation across the stem}

Variation in density of heartwood combined (i.e. HW) and sapwood combined (i.e. SW) in the radial direction is presented in Figs. 1 and 3, while variation at all the six positions across each stem (i.e. from OSW to IHW) is also presented in Fig. 2. Density of combined heartwood is usually higher than that of the combined sapwood for all the species with minor exceptions (Fig. 3A-D; Table 1). For instance, for the primary species (Fig. 3A, B), the two stem positions (HW and $\mathrm{SW})$ are of the same density only for the middle of the stem of $N$. diderrichii (Fig. 3A; Table 1).
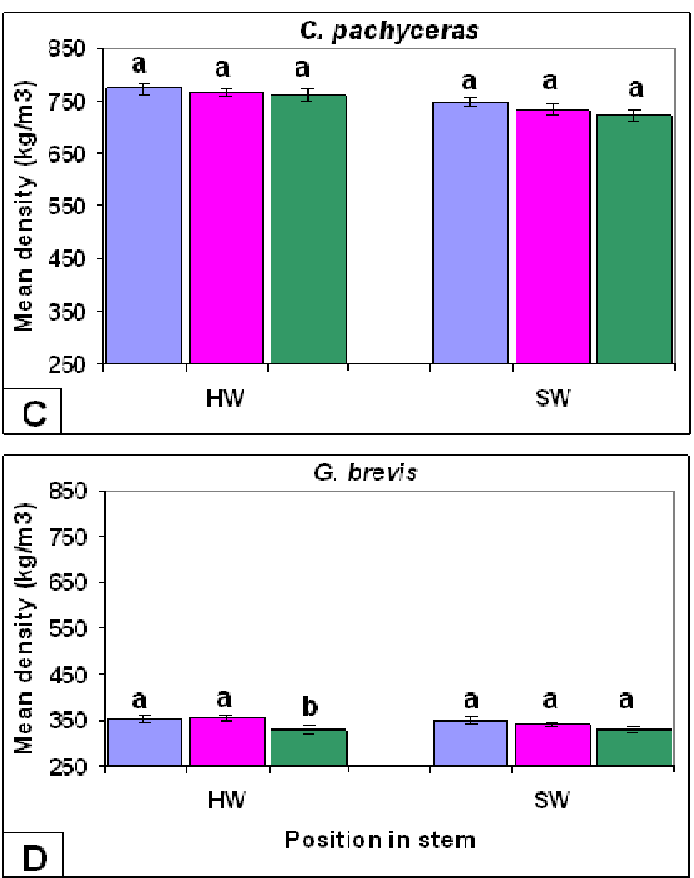

Figure 1: Mean densities of heartwood and sapwood along the stems of the selected Ghanaian hardwoods studied from all growth sites.

Note: $H W$ and $S W$ represent heartwood (combined) and sapwood (combined) respectively. Bars = standard errors. Bars with same letters are not significantly different $(p<0.05)$. 

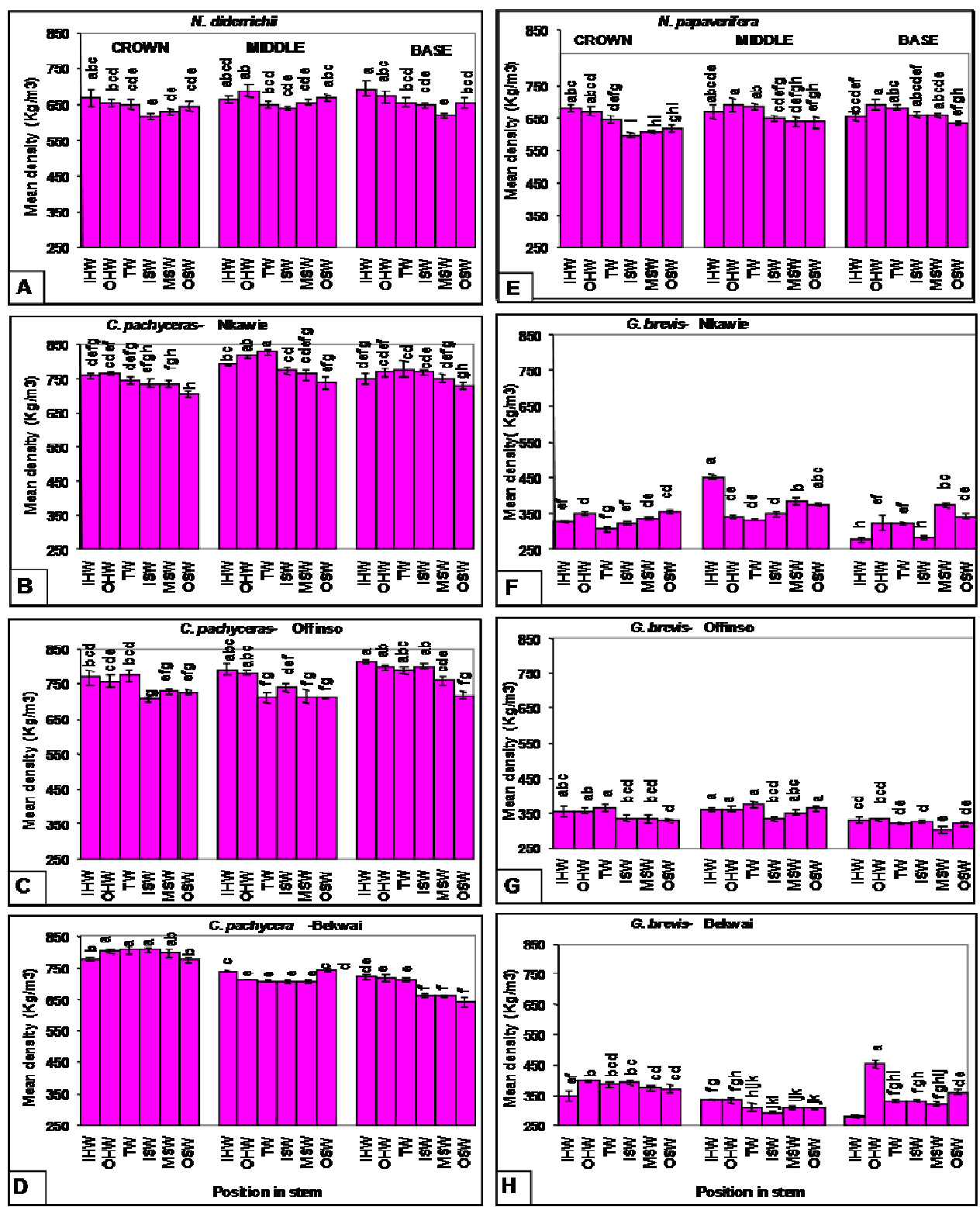

Figure 2: Mean densities of wood from different positions of the stems of the selected Ghanaian hardwoods studied

Note: IHW, OHW, TW, ISW, MSW and OSW represent inner and outer heartwood, transition wood, inner, middle, and outer sapwood respectively. Bars = standard errors. Bars with the same letters are not significantly different $(\mathrm{p}<0.05)$. 

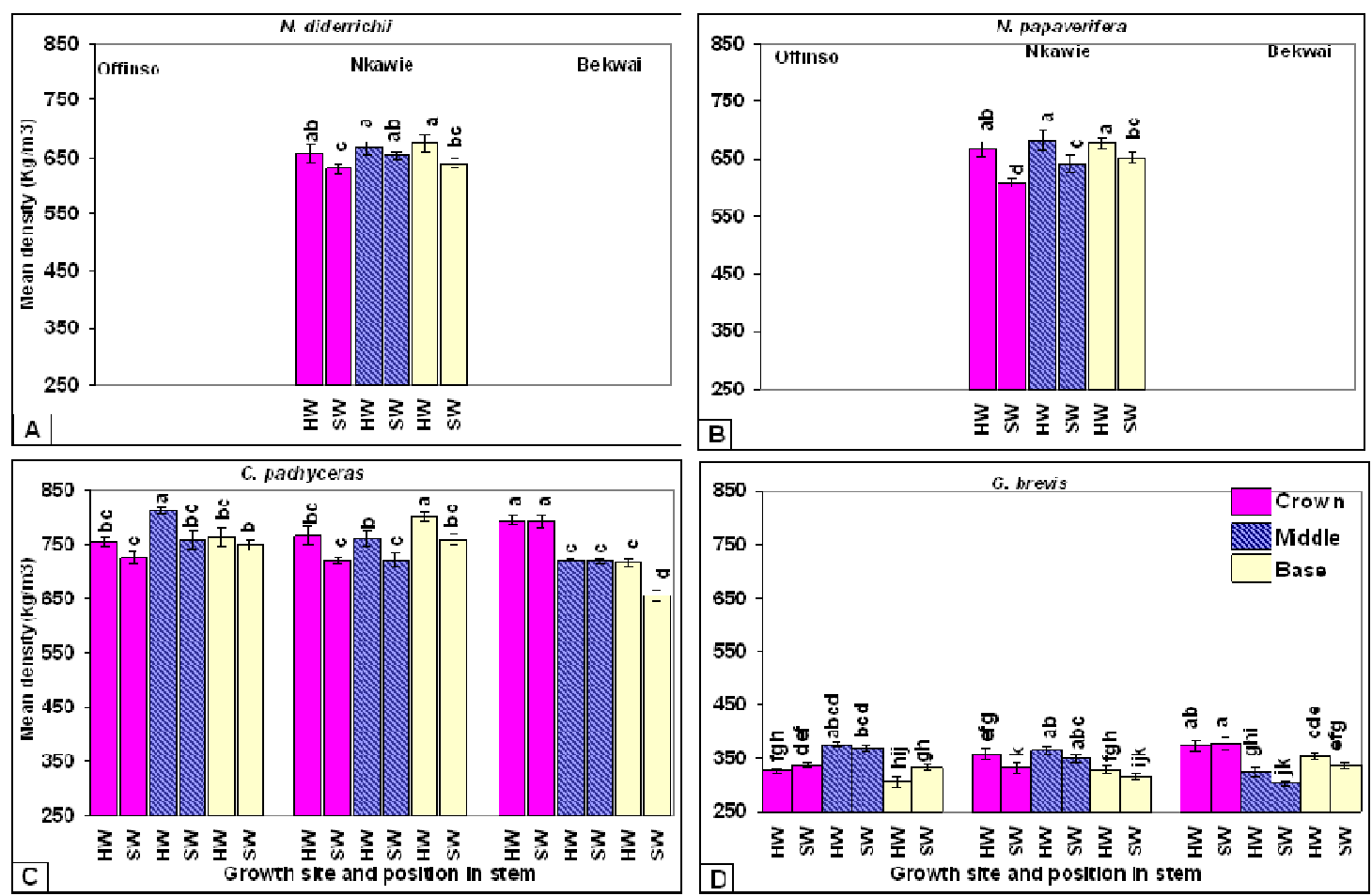

Figure 3: Mean densities of heartwood and sapwood of the selected Ghanaian hardwoods studied from different growth sites.

Note: $H W$ and $S W$ represent heartwood (combined) and sapwood (combined) respectively. Bars $=$ standard errors. Bars with the same letters are not significantly different $(p<0.05)$.

The trend was more inconsistent for the LUS (Fig. 3C, D). Density is greater for heartwood than sapwood only at the bases of the stems of $C$. pachyceras from Nkawie and Bekwai, and at the middle of Offinso and Nkawie (Fig. 3C). For $G$. brevis, heartwood is denser or heavier than sapwood only at the crown and base of the stem from Nkawie and the middle of the stem from Bekwai (Fig. 3D). Moreover, at all the six radial positions, the propensity for density to decrease from the inner growth ring (i.e. from IHW) to the outer ring (i.e. OSW) exists along the stems of all the four timbers (Fig. 2).

\section{Density variation along the stem}

Fig. 1 again shows that there is no regular trend in density variation for the combined heartwoods (HW) and combined sapwoods (SW) at the axial positions of the timbers except for $C$. pachyceras. For this species, HW densities at all the three axial positions are the same, as the differences between them are not significant $(p<0.05)$. This is also the same for the SW along its stems (Fig. 1C). This trend is not different for the heartwoods of $N$. papaverifera and sapwoods of $G$. brevis (all of Tiliaceae) (Fig. 1B and D respectively). However, the heartwoods of $N$. diderrichii and G. brevis are denser at the crown and middle regions than at the bases of their stems (Fig.1A and D), while this is the reverse for the sapwoods of the primary species ( $N$. diderrichii and $N$. papaverifera) (Fig. 1A and B). The differ-

70 Journal of Science and Technology, Vol. 29, No. 1, April, 2009 
Table 1: Within-stem density variation and density range for the four timbers under investigation

\begin{tabular}{|c|c|c|c|}
\hline \multirow[b]{2}{*}{ Timber species } & \multicolumn{2}{|c|}{ Density variation } & \multirow{2}{*}{$\begin{array}{l}\text { Density range for } \\
\text { stem positions }\end{array}$} \\
\hline & Radial & Axial & \\
\hline N. diderrichii & $\begin{array}{c}\mathrm{HW}>\mathrm{SW} . \\
\text { In middle, } \mathrm{HW}=\mathrm{SW}\end{array}$ & $\begin{array}{c}\text { For HW: } \\
\text { middle/crown }>\text { base } \\
\text { For } \mathrm{SW} \text { : base/middle }>\text { crown }\end{array}$ & $\begin{array}{l}660 \text { (ISW, crown) - } \\
720 \mathrm{~kg} / \mathrm{m}^{3} \text { (IHW, base) }\end{array}$ \\
\hline N.papaverifera & $\mathrm{HW}>\mathrm{SW}$ & $\begin{array}{l}\text { For HW: base }=\text { middle }=\text { crown } \\
\text { For SW: base } / \text { middle }>\text { crown }\end{array}$ & $\begin{array}{l}640(\mathrm{ISW}, \text { crown })- \\
700 \mathrm{~kg} / \mathrm{m}^{3} \text { (OHW, } \\
\text { base) }\end{array}$ \\
\hline \multirow{6}{*}{ C. pachyceras } & & DFFINSO & \multirow{6}{*}{$\begin{array}{l}720 \text { (OSW, base, Bek- } \\
\text { wai) }-820 \mathrm{~kg} / \mathrm{m}^{3} \text { (TW, } \\
\text { middle, Nkawie) }\end{array}$} \\
\hline & $\begin{array}{c}\mathrm{HW}>\mathrm{SW} . \\
\text { At crown, } \mathrm{HW}=\mathrm{SW}\end{array}$ & $\begin{array}{c}\text { For HW and SW: } \\
\text { base=middle=crown }\end{array}$ & \\
\hline & \multicolumn{2}{|r|}{ NKAWIE } & \\
\hline & $\begin{array}{c}\mathrm{HW}=\mathrm{SW} . \\
\text { In middle, } \mathrm{HW}>\mathrm{SW}\end{array}$ & $\begin{array}{c}\text { For } \mathrm{HW} \text { and } \mathrm{SW} \text { : } \\
\text { base }=\text { middle }=\text { crown }\end{array}$ & \\
\hline & \multicolumn{2}{|r|}{ BEKWAI } & \\
\hline & $\begin{array}{c}\mathrm{HW}=\mathrm{SW} . \\
\text { At base, } \mathrm{HW}>\mathrm{SW}\end{array}$ & $\begin{array}{c}\text { For HW and SW: } \\
\text { base }=\text { middle=crown }\end{array}$ & \\
\hline \multirow{6}{*}{ G. brevis } & & DFFINSO & \multirow{6}{*}{$\begin{array}{l}295 \text { (IHW, base, } \\
\text { Nkawie) - } 400 \mathrm{~kg} / \mathrm{m}^{3} \\
\text { (IHW, middle, } \\
\text { Nkawie) }\end{array}$} \\
\hline & $\begin{array}{c}\mathrm{HW}>\mathrm{SW} . \\
\text { In middle, } \mathrm{HW}=\mathrm{SW}\end{array}$ & $\begin{array}{l}\qquad \text { For HW: } \\
\text { middle/crown }>\text { base } \\
\text { For SW: base=middle=crown }\end{array}$ & \\
\hline & & NKAWIE & \\
\hline & $\begin{array}{c}\mathrm{HW}=\mathrm{SW} . \\
\text { At crown, } \mathrm{SW}>\mathrm{HW}\end{array}$ & $\begin{array}{c}\text { For HW: } \\
\text { middle/crown }>\text { base } \\
\text { For SW: base=middle }=\text { crown }\end{array}$ & \\
\hline & \multicolumn{2}{|r|}{ BEKWAI } & \\
\hline & $\begin{array}{c}\mathrm{HW}=\mathrm{SW} . \\
\text { In middle, } \mathrm{SW}>\mathrm{HW}\end{array}$ & $\begin{array}{c}\text { For HW: } \\
\text { middle } / \text { crown }>\text { base } \\
\text { For SW: base=middle=crown }\end{array}$ & \\
\hline
\end{tabular}

$H W$ and $S W$ represent heartwood (combined) and sapwood (combined) respectively.

ences between the densities are significant $(\mathrm{p}<$ $0.05)$. Fig 2 shows that the trend in variation in density for the individual sapwood regions (i.e. OSW to ISW) along the stems of all the four timbers was more irregular than for their combined sapwoods. Similarly, this is the situation for all the heartwoods at the axial positions (i.e. from IHW to TW) compared with their combined heartwoods.
Density variations within the stems of the LUS from different growth regions

The influence of growth site on density is presented in Fig. 3C and D for the two LUS. Once again, the trend is inconsistent. Fig. 3C shows that for trees of $C$. pachyceras from the three (3) forest regions, heartwood density is greater in the middle than at the base and crown regions from Offinso, in the base than in the middle and crown 
regions of the stems taken from Nkawie, and in the crown than at the base and in the middle of the stem from Bekwai. Density of the sapwood does not change along the stems sampled from Offinso and also those from Nkawie. However, the trend is consistent only for wood taken from Bekwai where density decreased from the base to the crown (i.e. crown $>$ middle $>$ base). For $G$. brevis, Fig. 3D shows that the heartwood in the middle of the stem from Offinso and Nkawie is of greater density than that at the base and crown regions. However, heartwood density of the stem from Bekwai follows this pattern: crown > base > middle. Density for its sapwood is greater in the crown and middle than at the base of the stem from Offinso, while that in the middle is more dense in the stem from Nkawie than at its base and crown. From Bekwai, the sapwood is most dense at the crown and least in the middle of the stem.

\section{DISCUSSION \\ Densities of timber species under investigation} Mean densities recorded for the two primary species (i.e. $N$. papaverifera and $N$. diderrichii) and C. pachyceras (i.e. LUS) at their bases in the present study differ from their published figures recorded by Bailey (1933) reported in Coday and Maun (1994) and Kribs (1959) respectively. Moreover, none of these authors indicated the stem positions where the densities of these hardwoods were determined. It should be stressed that no density value has been reported earlier for $G$. brevis. Thus, for the first time, its density has been determined to range between $295-400 \mathrm{~kg} / \mathrm{m}^{3}$, which is the lowest among the timbers studied. The lowest in density could be attributed to its largest vessel diameters (compared with those of the other three timbers). Such large pores usually contribute to provide a greater void volume, which makes such timbers light (Antwi-Boasiako, 2004).

Factors that influence density variation within species

Regarding the factors that could influence density variation within species, Brown, Panshin and Forsaith (1952) observed that at any given height, wood elements gradually increase in size in successive growth rings for sometime (often about 20-25 years). Thereafter, the mean size of the cells becomes relatively constant, subject to minor fluctuations often due to changes in the environment. It is logical to assume that such variations especially those affecting texture will be reflected in the high density of wood. For this reason, Tsoumis (1991) reported that in certain wood species (e.g. beech), density decreases with distance from pith especially in trees of the same species or between species due to the sizes and proportional amounts of cell types in their wood. According to Brown, Panshin and Forsaith (1952), the thickness of their cell walls can be a contributing feature as well. Other factors include differences in the amounts of extractives and other cell wall substances such as secondary metabolites including ash content (Antwi-Boasiako, 2004). Based on these and other factors, Brown, Panshin and Forsaith (1952) reported that at any given height in a tree-trunk, the density of the wood might vary considerably along a radius. According to Quilho and Pereira (2001), in hardwoods, within-stem variation could depend on the growth conditions prevailing at the time the wood was formed. From the foregoing, it is probable that several factors could contribute to account for the variation in density among hardwoods. Brown, Panshin and Forsaith (1952) reported that, of all the factors, cell wall thickness has the greatest influence on density. They also noticed that wood formed in the vicinity of the pith comprises cells that are smaller and probably have more extractives, thicker walls and smaller lumina than wood at greater distances in the outer growth rings. Such radial variations influence wood density, its strength and quality. Earlier report made by Tsoumis (1991) indicate that density decreases in several hardwoods with distance from pith as a result of anatomical differences between tree species, as has been the situation for the four timbers.

72 Journal of Science and Technology, Vol. 29, No. 1, April, 2009 
Density variation within the stems of the timber species

That the within-stem radial variation for the timbers showed density of heartwood (combined) was greater than for sapwood (combined), as was especially the situation at the bases of $C$. pachyceras and $N$. diderrichii, supports the studies made by Haack and Slansky (1987), Eaton and Hale (1993) and Debell et al. (1998) reported that heartwoods are mostly denser than sapwoods. These researchers emphatically explained that heartwoods consist of more dead cells with lignified cell walls and extractives that provide greater mechanical strength and offer more natural durability to wood than their counterpart sapwoods. These could explicate the present general trend in density variations among the four species, which has revealed the heartwoods of all the species to be of higher density than their corresponding sapwoods.

\section{Density variation across the timbers}

There were no significant differences in density ( $p<0.05$ ) between the various radial regions of the sapwoods of each timber as well as between the different positions, of the heartwoods on the other hand. This possibly reflects the fact that these positions, each of either the sapwood or heartwood, had almost the same concentrations of extractives and similar cell wall thickness within each stem. This observation has been reported by Antwi-Boasiako (2004) whose studies further revealed that these features could contribute as well to influence the durability variation in these regions of these timbers. Although no clear trend in density is followed for G. brevis and N. papaverifera (the Tiliaceae) in the present investigation, density increase from OSW to IHW at the base of the stem has been previously reported for $C$. pachyceras and $N$. diderrichii (the Rubiaceae) by the author. However, in G. brevis; the heartwood sometimes was the lightest, as it is in the case for its OHW and IHW from Nkawie and IHW from Bekwai (Fig. 2). A possible reason might be that, in such timbers, the previously formed extractives could degrade over time in the IHW (Hillis, 1987). Thus, Anderson et al. (1963) and Jin et al. (1988) also contended that decrease in density (and also durability) from the sapwood/ heartwood interface (i.e. transition wood [TW]) toward the pith, as has been revealed in the present study, is believed to reflect the possible natural oxidation of HW extractives, or continued depolymerization of extractives or microbial activity with age. Debell et al. (1998) asserted from many studies that, the highest levels of extractives have been found in OHW at the bases of trees. This is most exemplified for $G$. brevis especially for its stems from Nkawie and Bekwai.

\section{Axial density variation within the timbers}

Density has been found also to vary along stems decreasing with height, vice versa (Saranpää, 2003). Luxford and Markwardt (1932) in Brown, Panshin and Forsaith (1952) found the bases of redwood stems to be denser (about 15\%) than the crowns and partly attributed this to variations in heavier concentrations of heartwood extractives. Unsurprisingly, Brown, Panshin and Forsaith (1952) also reported a general trend for densities to decrease from the bases to the crowns of a number of stems. Their work is similar to the observation made for the greater number of the species under the present investigation. However, a few noticeable variations and irregularities were observed for the LUS especially from the different growth sites. Such deviations have since been observed by Saranpää (2003).

\section{Growth site and density variation}

It is significant to note that mean density variations of the LUS stems under investigation sampled from three different Ghanaian forest districts have indicated that growth site could contribute to influence wood density. Quilho and Pereira (2001) gave the explanation that prevailing growth conditions of an area during wood formation likely contribute to effect differences in density within hardwood stems such as these LUS. 


\section{CONCLUSION}

Generally, mean densities recorded for the two primary species ( $N$. diderrichii and $N$. papaverifera) and $C$. pachyceras (LUS) at their bases differ from the published figures. Moreover, density for the other LUS ( $G$. brevis) that has never been in existence has been determined to range between $295-400 \mathrm{~kg} / \mathrm{m}^{3}$.

Although variations in density within the stems of the four timbers exist, the trend is not normally consistent. However, on the whole, sapwoods are less dense than their heartwood counterparts. That is, within-stem radial variation indicates a general trend whereby the combined heartwood is heavier than the combined sapwood mostly at the butt regions especially for the present members of the Rubiaceae (i.e. C. pachyceras and N. diderrichii), as the differences in their densities are not significant ( $\mathrm{p}<0.05)$. Regarding the density in the six (6) individual positions across the stem, no clear trend is followed for the members of the Tiliaceae (i.e. G. brevis and N. papaverifera). For example, in $G$. brevis, the heartwood regions are occasionally the least dense such that OHW and IHW from Nkawie and IHW from Bekwai are the lightest. Nonetheless, a more consistent increase from OSW to IHW at the base of the stem has been reported for the two members of the Rubiaceae than for those of the members of Tiliaceae.

Furthermore, density varies along the stems of the four timbers often decreasing with height, with the bases being denser. However, there are few perceptible irregularities in the axial density trend especially for the LUS sampled from the three growth regions. Mean density variations indicate their stem densities are influenced by growth site.

For instance, Jozsa and Middleton (1994) observed that density variability of major North American hardwoods was a concern in the 1960 s and 1970 s due to problems regarding the properties of structural timbers and plywood from various combinations of species and smaller secondgrowth timbers. They reported that it is density uniformity that makes yellow-cypress, white pine and lodgepole pine such excellent carving and turning stocks. Veneer peeling and slicing are other end-users where the degree uniformity is significantly beneficial. Unfortunately, little information exists for the variability in wood density and its influence on the end-uses of the numerous tropical hardwoods.

Since density could affect several wood properties including strength and durability as well as their quality and marketability, the within-stem density variations of several other tropical species need examining, as this would contribute to determine the end-use of every stem position of each timber.

\section{ACKNOWLEDGEMENTS}

The authors thank The School of Plant Sciences of The University of Reading (England, UK), Forest Products Research Centre (FPRC) of Buckinghamshire Chilterns University College in High Wycombe (UK), The Royal Botanic Gardens (KEW, UK) for the staff, laboratories and equipment they offered to assist in the execution of this work in the UK. We also are grateful to the Government of Ghana for the financial support.

\section{REFERENCES}

Akhter, S. and Hale, M. D. C. (2002). Variation in Natural Durability of British Grown Douglas Fir (Pseudotsuga menziesii (Mirb.) Franco). Part 1. Effect of Density and Growth Rate. IRG/WP. Paper Prepared for the 33rd Annual Mtg., Cardiff, Wales (UK). 12-17 May, 2002. IRG Sec't, Stockholm, Sweden.14pp.

Anon. (1982). EN 113:6009. Wood Preservatives. Determination of the Toxic Values Against Wood-destroying Basidiomycetes Cultured on an Agar Medium.

Anon. (1994a). BS EN 350-1 - Durability of Wood and Wood-based Products - Natural Durability of Solid Wood. Part 1. Guide to the Principles of Testing and Classification of the Natural Durability of Wood.

Anon. (1994b). BS EN 350-2 - Durability of Wood and Wood-based Products - Natural 
Durability of Solid Wood. Part 2. Guide to Natural Durability and Treatability of Selected Wood Species of Importance in Europe.

Antwi-Boasiako, C. (2004). Assessment of Anatomy, Durability and Treatability of Two Tropical Lesser-Utilized Species and Two Related Primary Species from Ghana. PhD Thesis (2004) submitted to The University of Reading, Reading, England (UK). 319pp.

Bailey, I. W. (1933). The Cambium and its Derivative Tissues: VIII. Structure, Distribution and Diagnostic Significance of Vestured Pits in Dicotyledons. J. Arnold Arbor., 14, 259273. In: Coday, A. E. and Maun, K. W. 1997.

Barnett, J. R. and Jeronimidis, G. (2003). Wood Quality and its Biological Basis. Blackwell Publishing Ltd., Oxford, UK. CRC Press LLC, USA and Canada. 225pp.

Boyce, J. S. (1961). Forest Pathology. $3^{\text {rd }}$ ed. McGraw-Hill Book Co. Ltd. New York. S.572.

Brown, H. P., Panshin, A. J. and Forsaith, C. C. (1952). Textbook of Wood Technology. Vols. 1\&2. McGraw-Hill Book Company Inc. London.

Coday, A. E. and Maun, K. W. (1997). Identification of Hardwoods. A Microscopic Key. BRE Publications, Garston, 236pp.

Desch, H. E. and Dinwoodie, J. M. (1996). TIMBER: Structure, Properties, Conversion and Use. $7^{\text {th }}$ edn. McMillan Press Ltd., UK. 306pp.

Eaton, R. A. and Hale, M. D. C. (1993). Wood, Decay, Pests and Protection. $1^{\text {st }}$ edn. Chapman \& Hall, London \& Glasgow, UK. $546 \mathrm{pp}$.

Garren, K. H. (1939). Studies on Polyporus abientinus. 111. The Influence of Certain Factors on the Rate of Decay of Loblolly Pine Sapwood. J For., 37: 319-323.

Haack, R. A. and Slansky, F. Jr. (1987). Nutritional Ecology of Wood-feeding Coleoptera,
Lepidoptera, and Hymenoptera. $\underline{15}$. In: Nutritional Ecology of Insects, Mites, Spiders and related Invertebrates. Eds. Slansky, F. \& Rodrigues, J. G. (1987). Wiley-Interscience Publications. Pp. 449-486.

Hillis, W. E. (1987). Heartwood and Tree Exudates. Springer-verlag, Berlin. 268pp.

Jozsa, L. A. and Middleton, G. R. (1994). A Discussion of Wood Quality Attributes and their Practical Implications. Forintek Canada Corp. Western Laboratory, Vancouver, B.C. Special Publication No. SP-34. 42pp.

Kribs, D. A. (1959). Commercial Foreign Woods on the American Market. Ann Arbor. Mich., Edwards Brothers.

Nilsson, T. and Daniel, G. (1992). On the Use of \% Weight Loss as an Assessment for Expressing Results of Laboratory Decay Experiments. Working Group II; Fundamentals of Testing Document No.: IRG/WP/2394-92. IRG Sec't., Stockholm, Sweden. 5pp.

Quilho, T. and Pereira, H. (2001). Within- and Between-tree Variation of Bark Content and Wood Density of Eucalyptus globules in Commercial Plantations. IAWA Journal, 22 (3): 255-265.

Saranpää, P. (2003). Wood Density and Growth (Chpt. 4). In: Wood Quality and its Biological Basis. Blackwell Publishing Ltd., Oxford, UK. CRC Press LLC, USA and Canada. Eds. Barnett, J. R. \& Jeronimidis, G. (2003). $225 \mathrm{pp}$.

Schmidtling, R. C. and Amburgey, T. L. (1977). Growth and Wood Quality of Slash Pines after Early Cultivation and Fertilization. Wood Sci. 9: 154-159.

Tsoumis, G. (1991). Science and Technology of Wood Structure, Properties and Utilization. Chapman \& Hall, N.Y., London. 494pp.

Wong, B. M., Knoll, C. S. and Roy, D. N. (1993). The Chemistry of Decayed Aspen Wood and Perspectives on its Utilization. Wood Science Technology, 27(6): 439-448. 